\title{
Love-Based Leadership at School as a Way to Well-Being in Pupils_-Theoretical and Practical Considerations
}

\author{
Kaarina Määttä ${ }^{1}$ \& Satu Uusiautti ${ }^{2, *}$ \\ ${ }^{1}$ University of Lapland, PO Box 122, 96101 Rovaniemi, Finland \\ *Corresponding author: University of Lapland, PO Box 122, 96101 Rovaniemi, Finland. Tel: \\ 358-50-355-1280. E-mail: satu@uusiautti.fi
}

Received: March 6, 2014 Accepted: June 5, 2014 Published: July 29, 2014

doi:10.5296/ije.v6i3.6042ＵRL: http://dx.doi.org/10.5296/ije.v6i3.6042

\begin{abstract}
Teachers' authority relies partly on the mastery of substance but that is not enough if the purpose is to enhance students' overall growth, self-knowledge and well-being. In today's schools, a variety of new phenomena (e.g., multiculturalism, exclusion, etc.) challenges teachers' work. In this article, we will discuss the concept of love-based leadership in the light of teachers' work and as a combination of love and authority. The fundamental aim is to provide education activities that increase students' sense of meaning and fulfillment, in other words, happiness. The success of the Finnish education is greatly dependent on teachers, and, therefore, the purpose is to contemplate how students could be provided with experiences of success by employing love-based leadership at school.
\end{abstract}

Keywords: love-based leadership, human strengths and resources, student well-being, pedagogical love, pedagogical authority 


\section{Introduction}

Good teaching necessitates live interaction and the ability to work in an interacting relationship with students, teacher colleagues, and-increasingly in the modern world-the wider working environment and economic life surrounding the school system. A teacher's ability to join the school as a part of its unique position in the community strengthens the cultural and social task of the school. The fast changes, internationalization, and multiculturalism that take place in our society are demanding a new kind of professionalism from teachers: the emphasis is on teachers' societal responsibilities and their roles as active future makers (von Wright, 2009; Seidl \& Friend, 2002). According to Coleman (2009, p. 281): "Recent years have been marked by a notable increase, among researchers and policy makers alike, of interest in the themes of well-being in schools, the relationships between cognitive and non-cognitive aspects of learning, the importance of a 'good childhood', the balancing of instrumental with less readily definable purposes of education, concerns with resilience and with happiness.

We ground this article on a claim that happiness, as a major focus of positive psychology (see e.g., Linley et al., 2009; Schiffrin \& Nelson, 2010), can be taught and cultivated at school in order to not only enhance children's well-being, but also because of its other advantages, such as better school achievements. A particularly salient focus in our research project is to determine how the select scientific approaches might be used in elaborating research models for re-thinking and designing caring learning environment, students' psychosocial well-being and school communities, and for developing the models of love-based leadership in schooling context (see also Caldwell \& Dixon, 2010). The need for such applications and interventions is recognized and well-justified: According to Seligman et al. (2009, p. 295), "well-being should be taught in school on three grounds: as an antidote to depression, as a vehicle for increasing life satisfaction, and as an aid to better learning and more creative thinking."

We claim that love and authority are the core concepts of teacherhood and irreplaceable when reviewing modern teachers' work (Määttä \& Uusiautti, 2012b); we will discuss them through the concept of love-based leadership. The viewpoint is a part of the research project called "Love-based leadership - $\quad$ An interdisciplinary approach" (www.ulapland.fi/lovebasedleadership) at the University of Lapland, Finland. In this paper, we discuss how the above-mentioned goals could be achieved by employing love-based leadership at school. The purpose of the paper is to make definitions and build the theoretical foundation for the concept of love-based leadership in education, and then review some practical examples that contribute to the understanding of love-based leadership in practical teaching situations.

\section{What is Love-based Leadership?}

We base our idea of love-based leadership on love as the fundamental phenomenon. Basically, love means deep caring for others and it makes life worth living. In other words, love is an emotion of strong affection and personal attachment, but it is challenging to define love 
comprehensively (e.g. Määttä \& Uusiautti, 2011; 2013; Uusiautti \& Määttä, 2011; 2013a). For example, love can be seen as a virtue or strength representing human kindness, compassion, and affection (e.g. Seligman, Steen, Park, \& Peterson, 2005; Uusiautti \& Määttä, 2011). From this point of view, love not only exists in every one of us, but it can also be developed as a strength (Seligman, 2002), and it is, thus, learnable. Love is not just a romantic feeling (Arman \& Rehnsfeldt, 2006), but a comprehensive ability and resource in human life (see e.g., Sternberg \& Grajek, 1984). Indeed, love can be seen to consist of emotions, knowledge and skills, and action (Määttä \& Uusiautti, 2013)

Love is a concept that can be combined with leadership, too. For example, Caldwell and Dixon (2009) have defined love as of the organizational constructs that are freedom producing and empowering, and that improve self-efficacy. Followers respond to leaders' love and trust with increased commitment and loyalty, because these positive leader actions make them happy. This leads to a positive circle; happiness, on its part, leads to engagement, productivity, and satisfaction (see e.g., Chang \& Lee, 2007). Likewise, elements such as honesty, respect, and compassion when connected with high-quality performance and allowance of human errors and flaws improves well-being and commitment (see also Buss, 2000; Calori, 1995; Seligman et al, 2005).

The aforementioned introduction of love and leadership establishes the connection between these two concepts and well-being. Our understanding of well-being is closely connected with happiness and the sense of meaning. Actually, Viktor Frankl (1991) outlined important ideas about the meaning in a human being's life. According to his thoughts, people always try to search and find the meaning even if their all basic needs were fulfilled. Nowadays, the ideas have been also discussed widely in positive psychology. For example, Seligman (2002) distinguishes three kinds of levels in happiness: (1) pleasure and gratification, (2) embodiment of strengths and virtues, and (3) meaning and purpose. According to Ed Diener (1984) subjective well-being refers to a person's subjective assessment of his or her life and how desirable, pleasant, and good it is. Therefore, happiness is not an emotion, but merely a state or a manifestation of human progress (Diener, 2009), and the sense of meaningful life and fulfilling oneself in a purposeful manner in the world (Uusiautti, 2013).

What does love-based leadership consist of, then? Love-based leadership is about sensitive leaders who are committed in developing a culture that demonstrates concern for individual needs (Fairholm, \& Fairholm, 2000). Means of creating such a culture are, for example, ability to provide advice and guidance, as well as emotional and instrumental resources. These kinds of leaders would also encourage their followers to creativity and autonomous thinking, and to seize opportunities of developing and obtaining expertise (e.g. Popper \& Amit, 2009). Happy followers are expeditious, proud, and proactive, too.

Emotionally intelligent leaders (Campbell, 2007) are also authentic (Avolio et al., 2004). Furthermore, an ethic of caring establishes, instead of guiding principles to blindly follow, a moral touchstone for decision making (Bass, 1990; Hoyle, 2002). Transformational leaders project a vision that their followers believe in, they inspire and support the followers, and make them feel wanted and valuable to the organization (see also Fischer \& van Kleef, 2010). 
The latter leader type corresponds to our conception of love-based leadership.

How to employ the idea of love-based leadership in educational contexts, then? We consider teachers as leaders (see also Rutledge, 2008), who can act in ways and employ methods that focus on recognition and cultivating students' strengths. Next, we will move on discussing the special nature of teacher authority and possibilities of using love-based leadership in the classroom.

\section{Can Students Be Led Toward Goodness and Happiness-and Well-Being?}

Authority is a concept often addressed in pedagogical points of view, and it has been studied a great deal (Delpit, 1988; Pace \& Hemmings, 2007; Deutsch \& Jones, 2011). Nevertheless, it has been understood in a contradictory way for education and teaching (Applebaum, 1999; Seidl \& Friend, 2002; Langford, 2010). The basic situation is that the teacher is in an authoritative position compared to the student. Actually, this is not a problem as such, but the teacher must consider students as potentially equal subjects (Hare, 1993), which means that the teacher-student relationship aims at making students develop into responsible and independent individuals.

This viewpoint can be illustrated with the idea of love through Van Manen's work. Only if the teacher aims at influencing students through love, the act of influence can be considered authentic without any hidden agenda (Van Manen, 1991). Harjunen refers to the importance of pedagogical interaction (Harjunen, 2009) that is based on mutual trust and morally sustainable pedagogical action. Määttä and Uusiautti (2012b) have defined the connection between pedagogical love and authority in the following manner: "If pedagogical love and pedagogical authority are based on expertise-based respect, the learning atmosphere is warm and encouraging. Mutual respect supports empathy; students respect the teacher because of his or her expertise and regard the teacher as a sort of safe mainstay that they can rely on. The teacher trusts and believes in the students' abilities, respects their individuality, and helps them to enhance their balanced development and find their own strengths."

What does this mean to love-based leadership in schooling and teaching? Love appears in teaching as guidance toward disciplined work, but also as patience, trust, and forgiveness. Instead of paving the road and amusing students, teachers should concentrate on developing methods that enhance students’ positive growth and high-order learning (Määttä \& Uusiautti, 2011, 2012b). Love-based leadership in education does not turn back on hardships and difficulties, but helps dealing with them (e.g., van Manen, 1991; Hatt, 2005). According to our understanding, pedagogical tact is the key providing teachers with ability and eye on how to approach and interact with various students (Määttä \& Uusiautti, 2011, 2012b).

\section{Opportunities for Employing Love-Based Leadership at School}

While the theoretical foundation is important to the empirical research and pursuit for operationalization of the theory into pedagogical solutions of love-based leadership in 
education, the viewpoint can be complemented by the existing research on applications and practical solutions that contribute to the analysis. What follows is an introduction of various findings from practice that we consider relevant from the point of view of love-based leadership.

The fundamental idea is that the role of a teacher who uses love-based leadership is primarily focused on encouraging and rewarding the multitude of talents and strengths students have, by presenting opportunities for displays of these talents and strengths each day. In practice, the means can be quite simple, such as linking strengths to specific festivals and events throughout the school calendar, activities, such as the strengths-based classroom, victory logs, and celebrations of "what went well” (see Linley et al., 2009).

However, the teacher cannot consciously focus on students' strengths, if he or she is not self-conscious, meaning that the teacher has to be aware of the influence of his or her actions and methods on children (Peltokorpi et al., 2013). Therefore, it is important that the teacher makes self-assessments: A teacher can reflect and observe his or her way of teaching and interacting with students in order to find our whether he or she treats students fairly, is open-minded toward various learners and their backgrounds, and do on. Becoming aware of one's own style and level of tact in teaching enables one to move toward an ideal state. It is about the teacher's tact and situational flexibility (see also Määttä \& Uusiautti, 2012b).

In addition to teachers' reflective practice, love-based leadership includes positively-oriented and well-being-promoting actions toward students. Seligman et al. (2009) describe simple exercises through which they aimed to help students identify their signature strengths and to increase students' use of these strengths in daily life. Moreover, this intervention was to promote resilience, positive emotions and students' sense of meaning or purpose. The positive outcome of these studies made Seligman et al. conclude that well-being should and can be taught at school. Basically, the positive focus seemed, according to Seligman et al.'s study, to consist of relatively small things, such as changing speaking prompts (e.g. instead of asking students to describe negative events, teacher asked them to give a speech about when they were of value to others; religion teachers asked students to explore the relationship between ethics and pleasure and what gives life purpose and meaning; geography teachers asked students to consider how criteria for well-being might differ between various countries; PE-teachers focused on analyzing the successes of past games before the next game or lesson. The point in here was that well-being could be taught and with the teacher's lead, students would not only learn about it but their own well-being would increase as well. It is important to discover one's signature strengths. In Seligman, Teen, Park, and Peterson's (2005) study, long-term effects of increase happiness were perceived in exercises which aimed at using signature strengths in a new way and naming three good things in their life daily with explanations.

Another functional application is Appreciative Inquiry, which could also be employed in education by teachers who want to utilize love-based leadership. Appreciative Inquiry utilizes a cycle of 4 processes, which focuses on discover (the identification of organizational processes that work well), dream (the envisioning of processes that would work well in the 
future), design (planning and prioritizing processes that would work well), and destiny (the implementation (execution) of the proposed design) (Cooperrider, Whitney, \& Stavros, 2008).

In fact, there are interventions in the school world that are based on AI. For example, Calabrese (2006) found that approaching school-university partnerships through an appreciative inquiry theoretical perspective created an environment for building trust, sharing knowledge, and increasing bridging capital. In this research, discovering what is good also assisted in creating a parallel system that might become a model for other teachers and, as a result, teachers and administrators openly shared success stories of how they helped students to succeed and remain in school. In the next phase, "dream”, administrators and teachers shared their dreams and vision of school. In the design phase, the research team identified teacher strengths as a foundation to improve the educational practices in this particular school. Through the above-mentioned phases all the way from recognizing teachers' and administrators' strengths and dreams and making them public, this high school reported substantial progress in student achievement scores in mathematics and science. Likewise, Ryan et al. (1999) discovered that AI was a suitable strategy for initiating an affective and analytical micro-level reform within a single school. The fundamental notion was that instead of concentrating on what was done wrong, AI helps discovering what is done well and what could be done more.

Strength-based methods as a part of love-based leadership necessitate providing students with daily experiences of success and positive learning events that enhances skills and cognitive development in students (Chafouleas \& Bray, 2004). Fredrickson (2001) considers pride as one distinct positive emotion that follows personal achievements and in order to feel pride one has to succeed; that can happen by adjusting goals and planning learning tasks in a way that each student can have the experience of achieving a goal. Teachers who use love-based leadership tries to find a balance between students' abilities and school-related expectations, chances and challenges. It is worth noticing that perceived successes also help in strengths-spotting in a crucial manner (see e.g., Popov, 1997).

Thus far, we have introduced elements and singular methods that contribute to the idea of love-based leadership in teaching, inside the classroom. However, a teacher's actions are not limited inside the classroom only. An important part of today's teachers' work is related to co-operation with parents and other partners of the school (Uusiautti, Määttä, \& Määttä, 2013). Consequently, love-based leadership has to be considered an all-encompassing state and likewise, love-based practices have to extend beyond the classroom. According to Hoover-Dempsey and Sandler (1997), parental involvement in education has long been a topic of interest among those concerned with optimal developmental and educational outcomes for school children. Likewise Epstein and Dauber (1991) noticed that when teachers make parent involvement part of their regular teaching practice, parents increase their interactions with children and feel more positive about their changes of helping their children and about teachers, too (see also Izzo et al., 1999). The best outcome is, naturally, that students do better at school, improve their attitudes and achievement. Teachers' love-based practices in co-operation with students' parents, thus, provide students with positive experiences regarding home-school relationship. 
As the examples introduced here showed, in love-based leadership practices in education, the academic success is only one element that is merely seen as the positive outcome of paying attention to children's well-being and positive attitudes (see also Huebner et al., 2009). The idea is that these positive experiences of accepting oneself as is and having positive relationships with peers and teachers boost their learning achievements in various school subjects. Methods and techniques that enhance students' self-awareness, recognition the good in themselves, therefore, do not only produce good and happy mood, but help identifying strengths and talents that can influence considerably on the academic success as well. Simultaneously, teachers come to teach well-being and happiness.

\section{Discussion}

The fundamental aims of love-based leadership and teaching are similar to the research themes, such as well-being, happiness, quality of life, and positive feelings, being introduced by positive psychology (Seligman et al., 2005; Seligman, Parks, \& Steen, 2004). In this ideology teachers are encouraged to enhance flourishing in students-and, fundamentally, it can lead to well-being in teachers, too (Storh, 2009). Teachers as love-based leaders set an example by directing our mindful and loving action in children and other people as well.

Love-based leadership could therefore act as a means to lead and guide students toward "the Meaningful Life”, as Seligman calls it (see e.g. Seligman et al., 2009, p. 296). Similarly, Greer's (2002) definition of a leader who trusts and respects followers and, thus, enhance their followers success is close to a teacher's love-based leadership in the classroom: Teacher as a caring leader or pedagogical authority has the possibility to help bringing out the best in pupils (see also Goleman, 2006). Then, the process moves forward-yet, not only the process of learning and performing, but also the process of discovering and using pupils' signature strengths and promoting well-being and happiness in life. This is a purest and noblest manifestation of adults primarily working for the benefit of children (Saevi \& Eilifsen, 2008). The ability to create happiness without trying to turn children into something that they are not is an important skill for a good educator and teacher (von Wright, 2009).

The Finnish teacher education has traveled a long and successful road being recognized through numerous international comparisons. Likewise, teachers are highly respected professionals in the Finnish society (Uusiautti \& Määttä 2013b; 2013c). Various eras, theories, and ideologies have had their own emphases in the illustration of a good teacher (Määttä \& Uusiautti, 2012b; Uusiautti \& Määttä, 2013c), but still teachers’ ability to bring out the good and moral in children are more topical than ever (Määttä \& Uusiautti, 2012a; 2013; Uusiautti \& Määttä, 2012). Now, Finnish teacherhood starts to have a greater emphasis on the caring and respectful teaching. Indeed, the teacher's role and position put demands on teachers' work-perhaps, now it is time to move toward a teacherhood that combines love and authority in a balanced manner. That is called love-based leadership in education. 


\section{References}

Arman, M., \& Rehnsfeldt, A. (2006). The presence of love in ethical caring. Nursing Forum, 41(1), 4-12.

Avolio, B. J., Gardner, W. J., Walumba, F. O., Luthans, F., \& May, D. R. (2004). Unlocking the mask: a look at the process by which authentic leaders' impact follower attitudes and behaviours. Leadership Quarterly, 15, 801-823. http://dx.doi.org/10.1016/J.LEAQUA.2004.09.003

Buss, D. M. (2000). The evolution of happiness. American Psychologist, 55(1), 15-23. http://dx.doi.org/10.1037/0003-066X.55.1.15

Calabrese, R. L. (2006). Building social capital through the use of an appreciative inquiry theoretical perspective in a school and university partnership. International Journal of $\begin{array}{lll}\text { Educational } \quad \text { Management, } & \text { 20(3), }\end{array}$ http://dx.doi.org/10.1108/09513540610654146

Caldwell, C., \& Dixon, R. D. (2010). Love, forgiveness, and trust: critical values of the modern leader. Journal of Business Ethics, 93, 91-101. http://dx.doi.org/10.1007/s10551-009-0184-z

Calori, R. (1995). Management in Europe: Learning from different perspectives. European Management Journal, 13(1), 58-66. http://dx.doi.org/10.1016/0263-2373(94)00058-F

Campbell, C. R. (2007). On the journey toward wholeness in leader theories. Leadership \& Organization Development Journal, 28(2), 137-153. http://dx.doi.org/10.1108/01437730710726831

Chafouleas, S. M., \& Bray, M. A. (2004). Engagement, disengagement, coping, and catastrophe. In A. J. Elliot \& C. S. Dweck (Eds.), Handbook of competence and motivation (pp. 527-547). New York, NY: The Guilford Press.

Chang, S.-C., \& Lee, M.-S. (2007). A study on relationship among leadership, organizational culture, the operation of learning organization and employees' job satisfaction. Learning Organization, 14(2), 155-185. http://dx.doi.org/10.1108/09696470710727014

Coleman, J. (2009). Well-being in schools: Empirical measure, or politician's dream? Oxford Review of Education, 35(3), 281-292. http://dx.doi.org/10.1080/03054980902934548

Cooperrider, D. L., Whitney, D., \& Stavros, J. M. (2008). Introduction. In D. L. Cooperrider, D. Whitney, \& J. M. Stavros (Eds.), Appreciative inquiry handbook. For leaders of change (pp. xv-xxix). San Francisco, CA: Berrett-Koehler Publishers.

Delpit, L. D. (1988). The silenced dialogue; Power and pedagogy in educating other people's children. Harvard Educational Review, 58(3), 280-298.

Deutsch, N. L., \& Jones, J. N. (2011). 'Show me an ounce of respect': Respect and authority in adult-youth relationships in after-school programs. Journal of Adolescent Research, 23(6), 667-688. http://dx.doi.org/10.1177/0743558408322250 
Diener, E. (1984). Subjective well-being. Psychological Bulletin, 95(3), 542-575.

Diener, E. (2009). Introduction-The science of well-being: Reviews and theoretical articles by Ed Diener. In E. Diener (Ed.), The science of well-being (pp. 1-10). New York, NY: Springer. http://dx.doi.org/10.1007/978-90-481-2350-6

Epstein, J. L., \& Dauber, S. L. (1991). School programs and teacher practices of parent involvement in inner-city elementary and middle schools. The Elementary School Journal, 91(3), 289-305.

Fairholm, M. R., \& Fairholm, G. (2000). Leadership amid the constraints of trust. Leadership \& Organization Development Journal, 21(1/2), 102-109. http://dx.doi.org/10.1108/01437730010319192

Fischer, A. H., \& van Kleef, G. A. (2010). Where have all the people gone? A plea for including social interaction in emotion research. Emotion Review, 2(3), 208-211. http://dx.doi.org/10.1177/1754073910361980

Frankl, V. E. (1991). Man's search for meaning. An introduction to logotherapy. A revised and enlarged edition of from death camp to existentialism. ( $6^{\text {th }}$ ed.) New York, NY: Simon and Schuster.

Fredrickson, B. L. (1998). What good are positive emotions? Review of General Psychology, 2(3), 300-319. http://dx.doi.org/10.1037/1089-2680.2.3.300

Goleman, D. (2006). The socially intelligent leader. Educational leadership, 64(1), 76-81.

Greer, M. E. (2002). Trust seals leadership. Professional Safety, 47(5), 8.

Hare, W. (1993). What makes a good teacher: Reflections on some characteristics central to the educational enterprise. London \& Ontario: The Althouse Press.

Harjunen, E. (2009). How do teachers view their own pedagogical authority? Teachers and Teaching: Theory and Practice, 15(1), 109-129. http://dx.doir.org/10.1080/13540600802661345

Hatt, B. E. (2005). Pedagogical love in the transactional curriculum. Journal of Curriculum Studies, 37(6), 671-688. http://dx.doi.org/10.1080/00220270500109247

Hoover-Dempsey, K. V., \& Sandler, H. M. (1997). Why do parents become involved in their children's education? Review of Educational Research, 67(1), 3-42. http://dx.doi.org/10.3102/00346543067001003

Hoyle, J. R. (2002). Leadership and the force of love. Six keys to motivating with love. Thousand Oaks, CA: Sage.

Huebner, E. S., Gilman, R., Reschly, A. L., \& Hall, R. (2009). Positive schools. In S. J. Lopez \& C. R. Snyder (Eds.), Oxford handbook of positive psychology (pp. 561-568). Oxford: Oxford University Press.

Izzo, C. V., Weissberg, R. P., Kasprow, W. J., \& Fendrich, M. (1999). A longitudinal 
assessment of teacher perceptions of parent involvement in children's education and school performance. American Journal of Community Psychology, 27(6), 817-839. http://dx.doi.org/10.1023/A:1022262625984

Linley, P. A., Joseph, S., Maltby, J., Harrington, S., \& Wood, A. M. (2009). Positive psychology applications. In S. J. Lopez \& C. R. Snyder (Eds.), Oxford handbook of positive psychology (pp. 35-47). Oxford: Oxford University Press.

Määttä, K., \& Uusiautti, S. (2011). Pedagogical love and good teacherhood. In Education, 17(2). http://dx.doi.org/10.1007/978-94-6209-206-8_7

Määttä, K., \& Uusiautti, S. (2012a). How to raise children to be good people? Analytic Teaching and Philosophical Praxis, 22(1), 83-91.

Määttä, K., \& Uusiautti, S. (2012b). Pedagogical authority and pedagogical love - connected or incompatible? International Journal of Whole Schooling, 8(1), 21-39.

Määttä, K., \& Uusiautti, S. (2013). Many faces of love. Rotterdam: Sense Publishers.

Pace, J. L., \& Hemmings, A. (2007). Understanding authority in classrooms: A review of theory, ideology, and research. Review of Educational Research, 77(1), 4-27. http://dx.doi.org/10.3102/003465430298489

Peltokorpi, E.-L., Määttä, K., \& Uusiautti, S. (2013). How to ensure ethicality of action research in the classroom? In S. Uusiautti \& K. Määttä (Eds.), How to study children? Methodological solutions of childhood research (pp. 29-50). Rovaniemi: Lapland University Press.

Popov, L. (1997). The family virtues guide. Simple ways to bring out the best in our children and ourselves. New York, NY: Penguin Group.

Popper, M., \& Amit, A. (2009). Attachment and leader's development via experiences. The Leadership Quarterly, 20(5), 749-763. http://dx.doi.org/10.1016/j.leaqua.2009.06.005

Rutledge, L. (2009). Teacher leadership and school improvement: A case study of teachers participating in the teacher leadership network with a regional education service center. (PhD Diss., Texas State University-San Marcos, USA.)

Ryan, F. J., Soven, M., Smither, J., Sullivan, W. M., \& Van Buskirk, W. R. (1999). Appreciative inquiry: Using personal narratives for initiating school reform. Clearing House, 72(3), 164-167. http://dx.doi.org/10.1080/00098659909599620

Saevi, T., \& Eilifsen, M. (2008). 'Heartful' or 'heartless' teachers? Or should we look for the good somewhere else? Considerations of students' experience of the pedagogical good. Indo-Pacific Journal of Phenomenology, 8, 1-14.

Schiffrin, H. H., \& Nelson, K. Æ S. (2010). Stressed and happy? Investigating the relationship between happiness and perceived stress. Journal of Happiness Studies, 11, 33-39. http://dx.doi.org/10.1007/s10902-008-9104-7 
Seidl, B., \& Friend, G. (2002). Leaving authority at the door: Equal-status community-based experiences and the preparation of teachers for diverse classrooms. Teaching and Teacher Education, 18, 421-433. http://dx.doi.org/10.1016/S0742-051X(02)00007-0

Seligman, M. E. P. (2002). Authentic happiness. Using the new positive psychology to realize your potential for lasting fulfillment. New York, NY: FreePress.

Seligman, M. E. P. (2009). Positive education: positive psychology and classroom interventions. Oxford Review of Education, 35(3), 293-311. http://dx.doi.org/10.1080/03051980902934563

Seligman, M. E. P., Parks, A. C., \& Steen, T. A. (2004). A balanced psychology and a full life. Philosophical Transactions of the Royal Society B, 359, 1379-1381.

Seligman, M. E. P., Steen, T. A., Park, N., \& Peterson, C. (2005). Positive psychology progress. Empirical validation of interventions. American Psychologist, 60(5), 410-421.

Sternberg, R. J., \& Grajek, S. (1984). The nature of love. Journal of Personality and Social Psychology, 47(2), 312-329.

Storh, K. (2009). Minding others' business. Pacific Philosophical Quarterly, 90, 116-139. http://dx.doi.org/10.1037/0003-066X.60.5.410

Uusiautti, S. (2013). On the positive connection between success and happiness. International Journal of Research Studies in Psychology, 3(1), 1-11. http://dx.doi.org/10.5861/ijrsp.2013.509

Uusiautti, S., \& Määttä, K. (2011). The ability to love - a virtue-based approach. British Journal of Educational Research, 2(1), 1-19.

Uusiautti, S., \& Määttä, K. (2012). Can teachers teach children how to be moral. British Journal of Education, Society \& Behavioral Science, 2(3), 269-270

Uusiautti, S., \& Määttä, K. (2013a). Love-based leadership in early childhood education. Journal of Education, Culture and Society, 1, 109-120.

Uusiautti, S., \& Määttä, K. (2013b). Good teachers and good teacher educators: A glance at the current teacher education in Finland. Asian Journal of Education and e-Learning, 1(1), 1-6.

Uusiautti, S., \& Määttä, K. (2013c). Significant trends in the development of Finnish teacher training from the 1860s to 2010. Education Policy Analysis Archives, 21(59), 1-19.

Uusiautti, S., Määttä, K., \& Määttä, M. (2013). Love-based practice in education. International Journal about Parents in Education, 7(2), 134-144.

van Manen, M. (1991). The tact of teaching: The meaning of pedagogical thoughtfulness. London: Althouse Press.

von Wright, M. (2009). The shunned essentials of pedagogy: authority, love and mystery. Nordic Philosophy of Education Network NERA Annual Meeting, Trondheim, March 
7th 2009. 2014, Vol. 6, No. 3

http://oru.diva-portal.org/smash/record.jsf?pid=diva2:212954

\section{Copyright Disclaimer}

Copyright reserved by the author(s).

This article is an open-access article distributed under the terms and conditions of the Creative Commons Attribution license (http://creativecommons.org/licenses/by/3.0/). 